( О. О. Палюх, канд. техн. наук, доц., КПІ ім. Ігоря Сікорського, Київ, Україна

\title{
ДОСЛІДЖЕННЯ ВПЛИВУ ДИСКРЕТНОГО НАНЕСЕННЯ КЛЕЮ НА МІЦНІСТЬ ПІВЖОРСТКИХ КНИЖКОВО-ЖУРНАЛЬНИХ ОБКЛАДИНОК
}

Дослідження можливостей мінімізації кількісного застосування клейових полімерних композицій, при виготовленні півжорстких книжково-журнальних обкладинок,

за рахунок дискретного нанесення клею суцільним стрічковим методом із повздовжнім, або поперечним напрямком, а також комірковим шаховим методом, виявили непропорційні відмінності у міцності утворених обкладинок і геометричною площиною заповнюваності клеєм.

Ключові слова: півжорстка обкладинка; розгортка обкладинки; стрічкове нанесення клею; коміркове нанесення клею; дискретне склеювання.

\section{Постановка проблеми}

Завданням дослідження є визначення умов і виробничих можливостей для створення додаткової міцності і жорсткості книжково-журнальних обкладинок, що за конструктивною просторовою побудовою складаються з однієї деталі, розгортка якої висічена із цілісного аркуша щільного крейдованого паперу або тонкого картону хром-ерзацу.

Геометрія додаткових крайок і клапанів, що після нанесення на них палітурного клею і загинання в сторону внутрішньої частини обкладинки утворюють подвійну товщину і додаткову міцність, порівняно із одинарними або подвійними не проклеєними обкладинками, потребує експериментального дослідження наступних можливостей:
- визначити умови збереження міцності подвійних проклеєних півжорстких книжково-журнальних обкладинок при скороченні витрат клею, за рахунок його дискретного нанесення і можливої економії клею, що сприяє зменшенню витратної частини вартості замовлення на виготовлення книжково-журнальної продукції;

- виявити умови, за якими можливе нанесення клею для приклеювання крайок і клапанів не суцільним шаром, що криє всю поверхню, а дискретним, що криє з визначеним кроком, лише частину внутрішньої поверхні такого типу обкладинок.

\section{Аналіз попередніх} досліджень

Вивченню процесів виготовлення палітурок і обкладинок 
для книжково-журнальної продукції, з метою мінімізації витрат палітурних матеріалів і формування конкурентоспроможної споживчої ціни в сучасному щільно конкурентному середовищі, що вимагає високої доцільності в застосуванні поліграфічних технологічних процесів та їх постійного вдосконалення, присвячено роботи багатьох українських та іноземних вчених.

У дослідженнях [1] визначено залежності змін у міцності одиничних, подвійних та склеєних зразків палітурних матеріалів, що мають прикладне значення при підбиранні компонентів виготовлення книжково-журнальних оправ з мінімізованими економічними показниками.

Застосування порівняльних коефіцієнтів [2] маси паперів і тонких картонів, із яких виготовлюють півжорсткі книжково-журнальні обкладинки, у поєднанні із порівняльними коефіцієнтами міцності, що визначені при експериментальному руйнуванні зразків, дозволяє здійснювати системний підбір матеріалів для виготовлення півжорстких обкладинок, з метою дотримання мінімальних і достатніх їх показників, що коливаються залежно від форматів видань, обсягів сторінок і товщини корінцевої частини, відповідно.

В експериментальних дослідженнях [3] вирішувалось завдання вдосконалення клейових композицій для підвищення еластичності клейової плівки, міцності з'єднання, достатньої адгезії і когезії при нанесенні клею на палітурні матеріали. В дослідженні [4] обґрунтовано забезпечення збільшення клеючої сили, зменшення старіння і пліснявіння клеючої ПВА дисперсії шляхом введення антисептиків та омагніченої води.

Вивченню і дослідженню особливостей застосування різних видів палітурних клеїв та палітурних матеріалів, що використовуються для виготовлення книжково-журнальних оправ та дослідженню інших вимог до технологічних процесів сполучення клейових композицій, щільних паперів і тонких картонів, дозволяє моделювати [5] варіанти їх доцільного й економного поєднання, систематизує вибір конструктивних складових та сучасних технологічних можливостей.

\section{Мета роботи}

Експериментальне дослідження можливостей мінімізації кількісного застосування клейових полімерних композицій, при виготовленні півжорстких книжковожурнальних обкладинок, а також визначення впливу на їх міцність і експлуатаційну жорсткість технологічних процесів нанесення клею, суцільним або дискретним шаром однакової товщини.

\section{Результати проведених досліджень}

Виготовлення різноманітних конструкцій півжорстких обкладинок передбачає висікання будь-якої плоскої розгортки обкладинки із цілісного аркуша щільних палітурних матеріалів крейдованих паперів, хром-ерзаців і тонких картонів, геометрія яких складається із площини першої та другої сторінок обкладинки, за форматом видання і крайок та клапанів, що утворюють подвійну конфігурацію за товщи- 
ною у складеному із першою і другою сторінкою полю суцільної поверхні.

Окрім практично подвійної експлуатаційної міцності, отриманої за рахунок здвоєння двох тотожних поверхонь, однієї суцільної, а клапанної фрагментарної за рахунок внутрішнього проклеювання деталей утвореної подвійної просторової конструкції полімерними клейовими композиціями, додатково збільшуються показники міцності і жорсткості, які прямим чином впливають на тривалість використання спрощених обкладинок із однієї розгортки у книжковожурнальних виробах.

На рис. 1 представлено одну із конструкцій [6] проклеєної подвійної півжорсткої обкладинки, створення якої полягає у висіканні розгортки (1), як заготовки для виготовлення обкладинки, нанесення клейової полімерної композиції на площини додаткових конструктивних елементів у вигляді крайок і клапанів (2), їх фальцювання по лініях згинів, до утворення подвійної проклеєної площини (3), подальше щільне стискання утвореного тришарового виробу валиками механізму каландра, впродовж необхідного терміну полімеризації палітурного клею.

Виріб, який утворюється після перелічених технологічних процесів, за рахунок високої адгезії полімерних клейових композицій [7] у структуру сприятливих для цього палітурних матеріалів, відібраних як доцільних, для виготовлення спрощених півжорстких книжково-журнальних обкладинок, набуває властивості композитного тіла із зовнішніми шарами палітурного матеріалу і внутрішнього клейового шару, що після полімеризації утворив щільну жорстку пластину, структурно зв'язану із зовнішніми шарами.

Враховуючи те, що інтегральні та півжорсткі обкладинки займають проміжне становище між палітурками й обрізними обкладинками, підвищення їх міцності
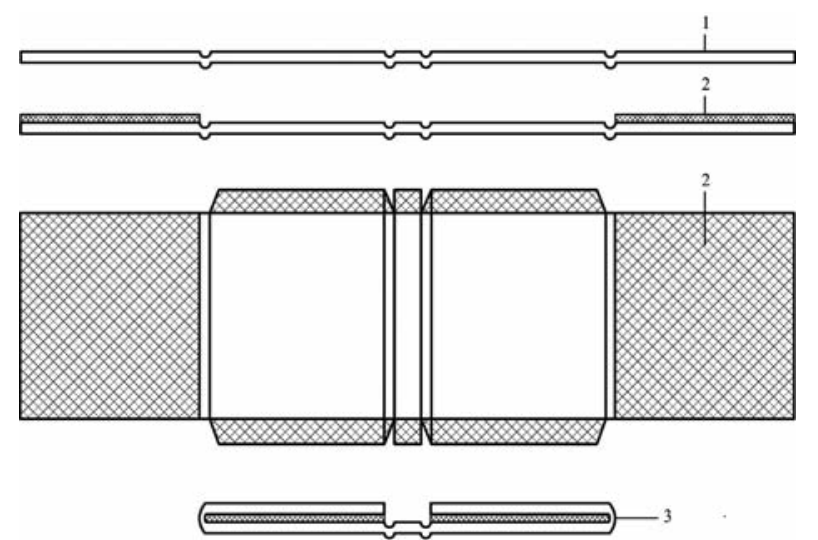

Рис. 1. Етапи нанесення клею та приклеювання крайок і клапанів розгортки півжорсткої обкладинки: 1 - висічена розгортка обкладинки;

2 - місця нанесення клею; 3 - завершена обкладинка після приклеювання крайок і клапанів 
за рахунок використання новітніх клейових композицій, технологій модифікування клейових композицій та інших діючих засобів, сприяє суттєвому підвищенню міцності, жорсткості та експлуатаційній стійкості таких обкладинок [8].

3 іншої сторони, засоби збереження міцності та стійкості півжорстких обкладинок, у яких клейовий шар, нанесений дискретно, з визначеним кроком, лише на частину поверхні склеювання і забезпечує тотожний рівень міцності, як за умов суцільного нанесення клею, потребують широкого застосування, через значну економію грошових коштів та забезпечення конкурентоздатної ціни усього книжковожурнального виробу.

До визначення технологічних можливостей модифікації доданої міцності клейових композицій [9] при виготовленні півжорстких обкладинок, розглянемо основні відмінності клейових валів клейових апаратів фальцювальносклеювальних ліній та технологій нанесення клею, за допомогою яких здійснюється суцільне і дискретне нанесення клею на конструктивні деталі висічених розгорток заготовок майбутніх обкладинок.

Необхідно зазначити, що виготовлення основних видів книжково-журнальних оправ таких, як обрізні та інтегральні обкладинки і палітурки різних конструкцій відрізняється не тільки комплексом технологічних операцій їх виготовлення, в яких враховуються відмінності побудови оправ, а і способом їх скріплення з книжково-журнальними блоками.
Обрізні обкладинки кріпляться до блоків незшивним клейовим способом лише до корінцевої частини блоку або до корінцевої частини з двосторонньою боковою промазкою. Для основної площини таких обкладинок відсутній будь-який вплив клейових речовин, що міг би змінити структуру матеріалу обкладинки і призвести до появи різноманітних дефектів, а також пришвидшеного експлуатаційного руйнування.

Інтегральні обкладинки кріпляться до книжково-журнальних блоків, як незшивним клейовим способом так і приклеюванням до форзаців книжкових блоків, на всю площину яких нанесені клейові полімерні композиції [10].

Враховуючи незначні розміри крайок в інтегральних обкладинках, на які суцільним шаром наносять палітурний клей, загинають по біговальних лініях і щільно притискають каландрувальними валками, утворюючи міцну, майже однорідну по периметру, конструкцію обкладинки, у якої приклеєні крайки виконують функцію умовного ребра жорсткості.

Відповідно, нанесення клейових композицій суцільним шаром на основну поверхню інтегральних обкладинок і приклеювання їх до форзаців книжкових блоків не призводить до виникнення дефектів скріплення обкладинки і блока, а також не змінює в сторону зменшення тривалість гарантійного експлуатаційного періоду [11].

Основною технологією виготовлення палітурок для книжкових блоків, попри конструктивне різноманіття палітурок, є приклеювання картонних сторонок до окантовувальних матеріалів 
таких, як видрукуваний і ламінований папір, палітурні матеріали штучного (баладек, балакрон) або природнього (шкіра) походження.

У такому сполученні, картон і окантовувальний матеріал, різниця в товщині перелічених складових палітурок вимагає нанесення лише суцільного шару клею на поверхню окантовувальних матеріалів і щільного притискання картонних сторонок до окантовувального матеріалу з подальшим обгортанням крайками цього матеріалу зворотної сторони утвореної палітурки.

В іншому випадку, дискретне нанесення клею, не суцільним шаром, на окантовувальний матеріал призводить до утворення пухирів різних розмірів, у місцях відсутності клею, що псує зовнішній вигляд виготовлених палітурок і призводить до їх відбраковування на стадії технологічного контролю.

Основна відмінність півжорстких обкладинок, від перерахованих книжково-журнальних оправ, полягає у однорідності щільних матеріалів, із яких утворена і основна частина, перша і друга сторінки обкладинки, і геометричні елементи обкладинки у вигляді клапанів і крайок, що утворюють подвійну суцільну проклеєну композитну структуру.

Для дослідження конструктивних особливостей деяких клейових апаратів, способів нанесення палітурних клеїв суцільними або дискретними шарами і чинників, що впливають на мінімізацію витрат клею для виготовлення півжорстких обкладинок, за умов дотримання їх визначеної технологічної міцності і жорсткості, присвячений подальший розгляд.
Клейові апарати, що застосовуються в палітурних технологічних процесах для нанесення клею суцільним шаром визначеної товщини, поділяються на два основні види, в одному із яких, товщину клейового шару регулює ракельний ніж, просторово дотичний до циліндричних валиків нанесення клею, в іншому механізм щілинного типу з регульованим пласким отвором подачі клею [12].

Клейові апарати для дискретного нанесення клею відрізняються конструктивними особливостями нанесення клейового шару (лише незмінної каліброваної товщини), який забезпечується циліндричними валками, що мають живильники заглиблення кругового типу в циліндричному тілі клейових валків, розташованих з кроком нанесення клею, або коміркову побудову поверхні (рис. 2).

На рис. 2., а зображено технологію нанесення каліброваного шару клею суцільними стрічкоподібними ділянками з товщиною клейового шару, позначеною, як

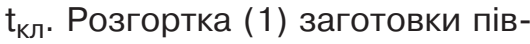
жорсткої обкладинки з товщиною палітурного матеріалу $\mathrm{t}_{\mathrm{m}}$ переміщається $\overrightarrow{\mathbf{V}}$ в напрямку обертового клейового валу.

Клейовий вал має однорідні ділянки заглиблення для наповнення клеєм, ширина яких позначена, як $\mathrm{s}_{1}$, проміжкові ділянки, як $\mathrm{S}_{2}$, що у випадку, зображеному на рис. $2, s_{1}=s_{2}$, діаметр заглиблення $-\mathrm{d}$, а діаметр зовнішньої поверхні, який обмежує кількість клею, що потрапляє в заглиблення і калібрує однорідність нанесення, як $\mathrm{d}_{\text {кл }}$. Відповідно, товщина клейового шару, який наноситься для склеювання обкладинки: 


$$
\mathrm{t}_{\mathrm{K} л}=\mathrm{d}_{\mathrm{Kл}}-\mathrm{d},
$$

а об'єм, що може бути нанесений за один оберт клейового валу:

$$
\mathrm{V}_{\text {кл }}=\left(\mathrm{d}_{\mathrm{Kл}}-\mathrm{d}\right) \cdot \mathrm{s}_{1} \cdot \mathrm{n},
$$

де $\mathrm{n}$ - кількість колових заглиблень однакової ширини.

Для планування і технологічного розрахунку витрат клею у виробництві необхідно враховувати лінійну довжину ділянки обкладинки, на яку наносять дискретний шар клею, тоді

$$
V_{L}=\frac{\left(d_{K ת}-d\right) \cdot S_{1} \cdot n}{\pi \cdot d} \cdot L
$$

де $\mathrm{V}_{\mathrm{L}}$ - витрати клею на фіксовану розмірами обкладинки довжину; L - лінійна довжина зони нанесення клею.

На рис. 2., б зображено технологію нанесення каліброваного шару клею комірковими клейовими валками. Утворююча поверхня такого клейового валка поділена на прямокутні ділянки з однаковими контурними розмірами $\mathrm{s}_{1}$.

Прямокутні ділянки чергуються у шаховому порядку в поздовжньому і поперечному напрямках утворюючої поверхні клейового валка: комірка-прямокутна ділянка-комірка-прямокутна ділянка, і так по всій утворюючій поверхні клейового валка.

Розміри комірок для поділу поверхні клейового валка вибрані такими, щоб могла бути відтворена їх кратна кількість, без залишків, для створення можливостей рівномірного нанесення клею на складові деталі обкладинок.

Комірки утворюючої поверхні клейового валка можуть мати різну геометричну форму на поверхні валка, у вигляді круглих отворів, чотири, п'яти, шести, або іншої конфігурації багатогранників.

У глибину валка, відраховуючи від утворюючої поверхні, формування отворів залежить від кон-
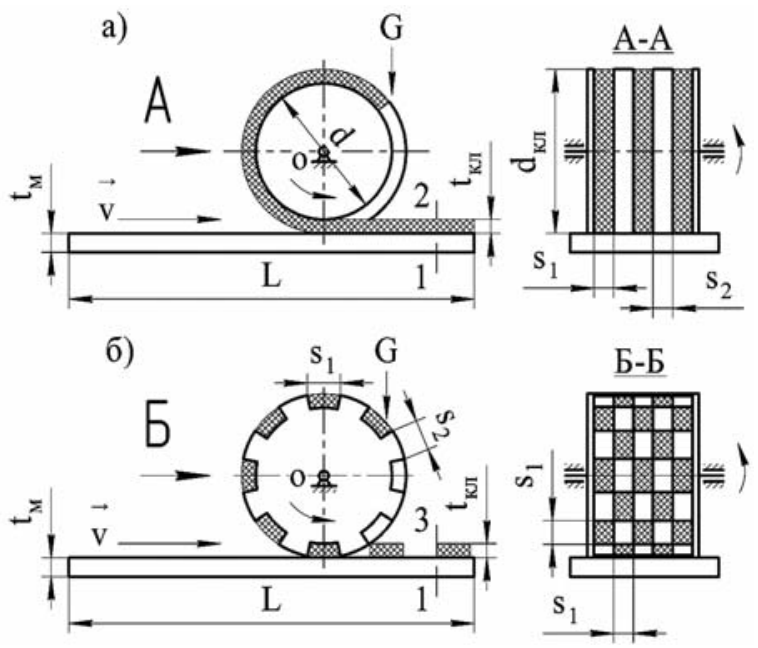

Рис. 2. Технології нанесення каліброваного шару клею: а - суцільного; б - дискретного 
фігурації металоріжучого інструменту, технології механічного утворення отворів і визначеної кількості клею, що має бути перенесена із комірок на обкладинку.

Для проведення співставних досліджень різних типів клейових апаратів і відмінностей у способах нанесення клею на деталі півжорстких обкладинок відібрані клейові валки з тотожними прямолінійними, для стрічкоподібного нанесення клею, і прямокутними, для коміркового нанесення клею, розмірними параметрами.

За умови однакових розмірів заглиблень і «пробільних» частин поверхні клейових валків, на які клей не наноситься, клейові апарати, як такі, що створюють шар клею суцільними стрічкоподібними ділянками, чи комірковими ділянками, утворюють параметрично тотожні площі клейового заповнення поверхонь конструктивних деталей обкладинок [13].

Але міцність виготовленої півжорсткої обкладинки, при нанесенні клею суцільними стрічкоподібними ділянками, буде відрізнятися в поздовжньому і поперечному напрямках залежно від напрямків нанесення клею (рис. 3).

Для технологічності операції нанесення стрічкоподібного шару клею доцільно використовувати валковий механізм, що здійснює нанесення клею при транспортуванні обкладинки в напрямку (1) показаному стрілкою на рис. 3 .

Нанесення клею у напрямку (2) ускладнює конструкцію клейового механізму, але створює більш сприятливі експлуатаційні умови використання півжорсткої обкладинки при тривалих розкриваннях книг і уповільнення отримуваної, відповідно, деформації обкладинок.

Для підготовки досліджень залежності площі нанесення палітурного клею на конструктивні деталі півжорстких обкладинок та отримуваної міцності і жорсткості виготовлених обкладинок, після склеювання основної частини обкладинки та її додаткових зміцнювальних деталей, необхідно дослідити процес розтискування клею при проходженні склеєних частин через валки механізму каландру [14].

Кількісний показник дискретної подачі клею клейовими валками та зусилля стискання склеєних поверхонь палітурного матеріалу півжорсткої обкладинки будуть суттєво впливати на отримувані геометричні параметри клейової площі заповнення утвореної композитної структури картонклей-картон.

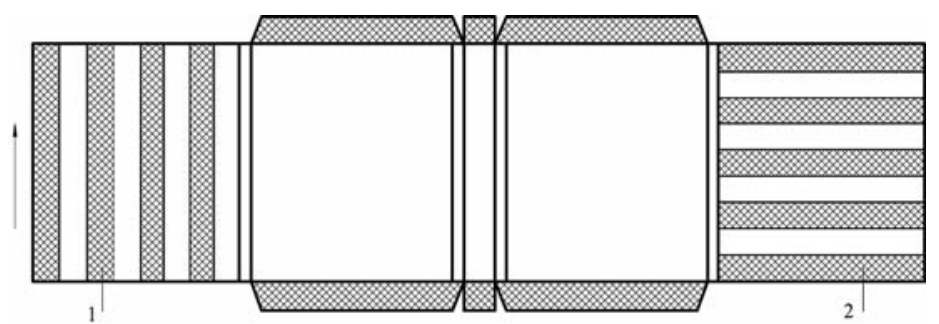

Рис. 3. Стрічкоподібні ділянки нанесення клею: $1-$ у поперечному напрямку; $2-$ у поздовжньому напрямку 
Клейові апарати, які наносять клей суцільним площинним шаром регулюють мінімальну товщину клею, враховуючи його липкість і в'язкість, у межах, що забезпечує надійне з'єднання склеєних поверхонь палітурного матеріалу півжорсткої обкладинки і заповнення профільного рельєфу, притаманного поверхням кожного матеріалу [15].

Будь-яке значне технологічне розтискування клею, після каландрування склеєних деталей одного щільного матеріалу, не планується і носить характер похибки. Наявність же значного розтискування, у таких випадках, свідчить про надмірну подачу клею, не викликану структурною необхідністю забезпечення додаткової міцності виготовленої обкладинки.

У випадку нанесення клею дискретними суцільними стрічковими, або комірковими шарами клею, порціонність нанесення клею залежить від конструкції клейових валиків, що сприяють забезпеченню технологічного розтискування клейового шару під час каландрування склеєних поверхонь обкладинок.

Площа утвореної дискретної зони склеювання не тільки забезпечує доцільну міцність і жорсткість обкладинок різних конструкцій, а $є$ елементом створення їх просторових варіантів.

Розглянемо декілька варіантів дискретного нанесення клейових шарів, зображених на рис. 4, для склеювання деталей півжорстких обкладинок і особливостей технологічного обґрунтування необхідності такого склеювання, де цифрами 1, 3, 5 позначені ділянки клейового валу без клею на поверхні, а 2, 4, 6 - ділянки каліброваних клейових впадин, що регулюють кількість нанесення клею.

Клейовий вал (рис. 4., а) має декілька радіальних колових пазів (2), утворених у тілі валу, що мають однакову ширину зі з'єднувальними елементами (1), розташованими в черговій послідовності з радіальними пазами. Ширина радіальних колових клейових пазів $\mathrm{t}_{1}$ і ширина з'єднувальних ділянок $s_{1}$ тотожні, тобто $t_{1}=s_{1}$.

Діаметр $\mathrm{d}_{1}$ позначає глибину радіального клейового пазу, що регулює порціонність нанесення клейового шару з однієї сторони. А діаметр $D_{1}$ позначає, як загальний зовнішній розмір циліндричної утворюючої поверхні клейового валу і циліндричний розмір з'єднувальних ділянок, так і зовнішній розмір клейового шару розташованого в радіальних колових пазах.

На рис. 4, а 1 відтворена прямокутна частина клапана півжорсткої обкладинки, що приклеюється до основної частини обкладинки, позначена сторонами $\mathrm{B}_{1}$ і $\mathrm{C}_{1}$ прямокутника. На поверхню клапану обкладинки нанесені стрічкоподібні шари клею шириною $t_{1}$ і товщиною $\tau_{1}$ (рис. $4, a_{2}$ ).

Товщина клею $\tau_{1}$ утворена нанесенням його в такій кількості, що забезпечує розтискування $\frac{\Delta_{1}}{2}$ за умови, що $\frac{\Delta_{1}}{2}=\frac{\mathrm{s}_{1}}{2}$. Загальна величина розтискування такого клейового шару $\Delta$ має бути тотожною з шириною з'єднувальних ділянок $\mathrm{s}_{1}$, на яких відсутній будь-який шар клею, $\Delta_{1}=\mathrm{s}_{1}$.

Враховуючи виконання попередньої умови, склеювані поверх- 
ні частин півжорсткої обкладинки при проходженні через стискаючі, з зусиллями $\overrightarrow{\mathrm{P}_{1}}$, валки каландру, перетворюють поверхню склеювання із дискретної у суцільну, із товщиною клейового шару $\tau_{2}\left(\tau_{2}+\tau_{1}\right)$.

З врахуванням розтискування клейового шару $\left(\mathrm{t}_{1}+\Delta_{1}\right)$, площа дискретного нанесення клею $\left(2_{1}\right)$, (рис. $4, a_{1}$ ) на прямокутну частину клапану обкладинки $\mathrm{B}_{1} \times \mathrm{C}_{1}$ набула суцільного характеру $\left(2_{2}\right)$, (рис. 4, а3).

Відмінність клейового апарату нанесення клею дискретними суцільними стрічковими ділянка- ми, які після розтискування механізмом каландру, перетворюються на суцільні клейові зони, порівняно із клейовими апаратами щілинного типу і циліндрично-ракельними, що потребують постійного регулювання товщини клейового шару, полягає в тому, що для виготовлення півжорстких обкладинок використовується клейовий вал з радіальними коловими пазами, що забезпечують незмінну калібровану кількість клею для нанесення на деталі обкладинки, з врахуванням розтискування, і не потребують налагоджень.

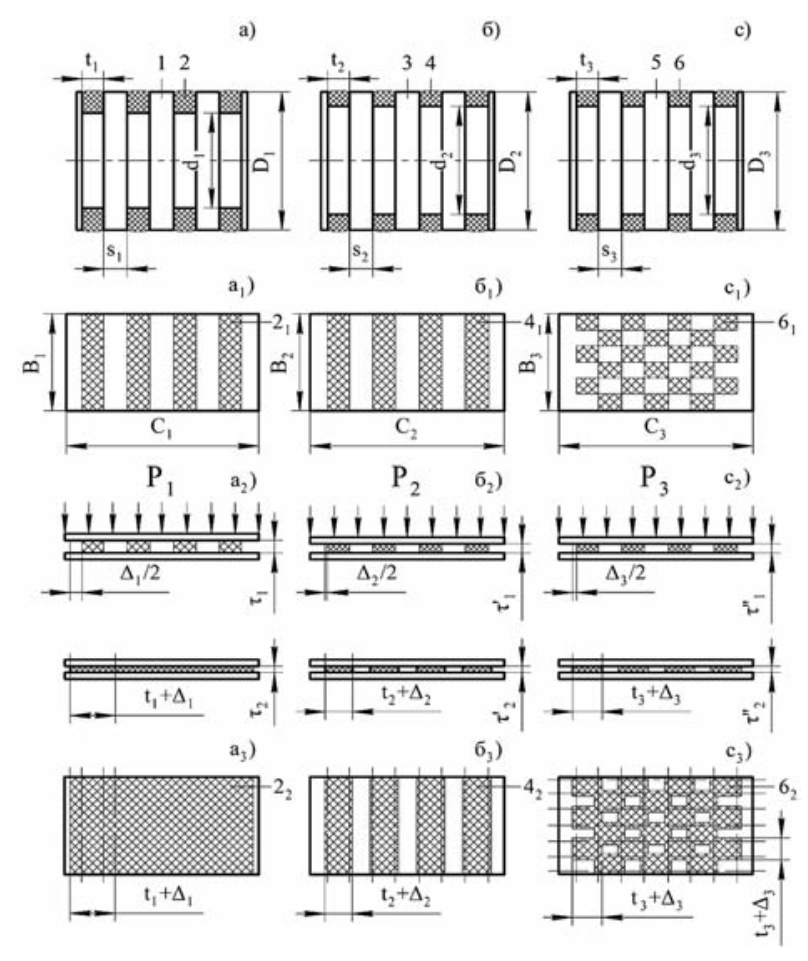

Рис. 4. Конструктивні особливості клейових валів і схем нанесення клею для виготовлення півжорстких книжково-журнальних обкладинок: 1, 3, 5 - клейові вали для нанесення суцільних і дискретних шарів клею; 2, 4, 6 - профільні заглиблення в клейових валах, що регулюють об'єм нанесеного клею на клеєні поверхні обкладинок 
Розглянемо інший варіант влаштування клейового апарату з дискретним нанесенням клею для виготовлення півжорстких обкладинок, представлений на рис. 4, б. Застосування півжорстких обкладинок у книжково-журнальній продукції, де скріплення обкладинок із книжковими або журнальними блоками відбувається незшивним клейовим способом, не вимагає однорідності склеєної композитної структури обкладинки і не потребує склеювання деталей обкладинки суцільним клейовим шаром.

3 метою мінімізації витратної частини замовлення, на виготовлення такої книжково-журнальної продукції, можливе застосування клейового апарату з економним дискретним стрічковим нанесенням клею на деталі обкладинки, з мінімальним його розтискуванням і збереженням зон вільних від клею.

У такому випадку, об'єм клею $\mathrm{V}_{\text {кл}}$, що має бути нанесений на фрагмент прямокутної частини клапана півжорсткої обкладинки, зі сторонами $\mathrm{B}_{2}$ i $\mathrm{C}_{2}$,буде дорівнювати:

$$
V_{\text {Кл }}=\left(D_{2}-d_{2}\right) \cdot t_{2} \cdot L \cdot n,
$$

де $D_{2}-$ зовнішній діаметр клейового валу і зовнішньої поверхні клею, що знаходиться в радіальних колових пазах; $d_{2}-$ внутрішній діаметр клейових колових пазів; $t_{2}$ - ширина клейового паза; L - довжина клейової стрічки; n - кількість клейових стрічок.

Товщина клейового шару $\tau_{2}^{\prime}$, з врахуванням розтискування:

$$
\tau_{2}^{\prime}=\frac{V_{\text {кл }}}{t_{2}+\Delta_{2}},
$$

де $\Delta_{2}$ - розмірний показник розтискування.

За умов рівності розмірів ширини клейових радіальних колових пазів і ділянок клейового валу вільних від клею $\left(t_{2}=s_{2}\right)$, площа внутрішньої заклеєної поверхні фрагменту клапана обкладинки, після каландрування (із притискним зусиллям $\overline{\mathrm{P}_{2}}$ ) і відповідного розтискування клею, збільшиться по ширині клейової стрічки порівняно з початковою, і буде дорівнювати:

$$
S=\frac{t_{2}+\Delta_{2}}{t_{2}} \cdot L \cdot n \cdot 100 \% .
$$

Можливий варіант стрічкового нанесення клею, в якому початкова ширина ділянок без клею більша за ширину ділянок з нанесеним клеєм на розмір подальшого розтискування, що дозволяє отримувати рівномірні ділянки після завершення склеювання і каландрування готового виробу. Відповідно:

$$
s_{2}>t_{2}=t_{2}+\Delta_{2} .
$$

Можливі й інші варіативні поєднання ширини стрічкових клейових шарів і проміжних ділянок між ними.

На рис. 4, с представлений клейовий вал коміркового типу, що здійснює нанесення клейового шару в шаховому порядку з перемінним чергуванням комірок з клеєм і з'єднувальних ділянок без клею.

Півжорсткі обкладинки виготовлені комірковим способом нанесення клею, з подальшим його незначним розтискуванням, придатні для з'єднання з книжковими блоками через приклеюван- 
ня до форзаців і не утворюють дефектів, як зовнішньої поверхні обкладинок, так і їх внутрішньої структури.

Розглянемо відмінність утвореної поверхні нанесення клею комірковим способом від попередньо перерахованих.

Необхідно відзначити, що стрічкове нанесення клею формує на площині склеюваної обкладинки суцільні поздовжні, або поперечні шари клею, відмінні від початкової ширини на величину розтискування $\Delta$.

Стрічкові клейові ділянки чергуються із стрічковими ділянками, на яких клей відсутній. У таких випадках заповнення клеєм площини обкладинки коливається в межах прямолінійних зон розтискування.

Шахове розташування комірок передбачає розмірне розтискування $\Delta_{3}$ (із зусиллям стискання $\overrightarrow{\mathrm{P}_{3}}$ ) клейових клітинок не лише в поздовжньому напрямку, а і в поперечному напрямку, що на відміну від стрічкового нанесення клею, суттєво зменшує поверхню обкладинки, на якій клей відсутній, на величину поперечного розтискування клітинок.

Для моделювання розрахунку площі шахового заповнення клеєм площини обкладинки, з врахуванням зон розтискування, введемо необхідні припущення. Довжина фрагменту обкладинки, на який наноситься клей, дорівнює довжині утворюючої клейового валика: $\mathrm{C}_{\text {кола }}=\mathrm{L}_{\text {обкл. Ширина клейо- }}$ вого валу дорівнює ширині фрагменту обкладинки, на якому розташовується довільна кількість клітинок, яка дорівнює цілому числу. Розміри клейових клітинок з розтискуванням і квадратних ділянок, на яких клей відсутній, тотожні.

Отже, для загального випадку, визначаємо кількість клітинок з клеєм і без клею, що можуть розташуватися на площині утворюючої клейового валу.

$$
\mathrm{n}=\frac{\pi \mathrm{D}}{2(\mathrm{t}+\Delta)}
$$

де D - діаметр клейового валу; $\mathrm{t}$ - розмір сторони клейової комірки; $\Delta-$ розмір двостороннього розтискування клею.

Загальна площа клейових комірок:

$$
S_{K}=\frac{\pi D}{2(t+\Delta)} \cdot t^{2} \cdot m,
$$

де $\mathrm{m}$ - кількість цілих рядів клітинок вздовж клейового валу.

Відповідно, загальна площа клейової поверхні, утвореної комірковим нанесенням клею, з врахуванням розтискування, дорівнює:

$$
\begin{aligned}
& \mathrm{S}_{\text {кл }}=\frac{\pi \mathrm{D}(\mathrm{t}+\Delta)^{2}}{2(\mathrm{t}+\Delta)} \cdot \mathrm{m}= \\
& =\frac{1}{2} \pi \mathrm{D}(\mathrm{t}+\Delta) \cdot \mathrm{m} .
\end{aligned}
$$

у подальших розрахунках для визначення площі клею, що наноситься комірковим клейовим валом на обкладинку, з параметрами формату видання, застосовуються коефіцієнти переходу, які враховують розміри клейового валу виробничого механізму нанесення клею, а також враховують довжину і ширину клейової ділянки обкладинки.

На рис. 5 зображені конструктивні особливості розташування 


\section{ТЕХНОЛОГІЧН І ПРОЦЕС И}
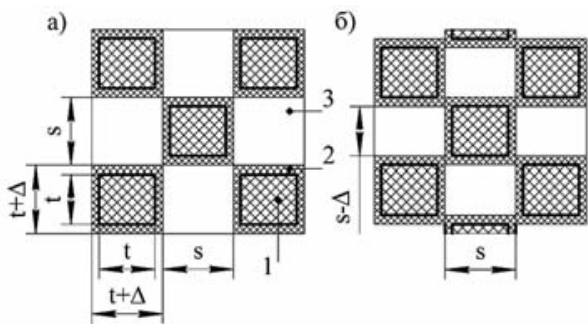

B)

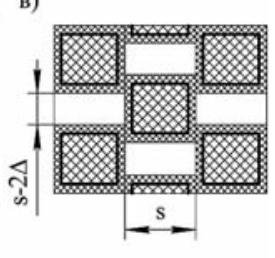

Рис. 5. Конструктивне розташування квадратних клейових комірок і послідовна зміна площі нанесення клею: а - шахове розташування зон нанесення клею з розтискуванням; б, в - розташування зон нанесення клею зі зміщенням; 1 - зона комірки; 2 - зона розтискування; 3 - зона вільна від клею

клейових зон, утворених комірковими клейовими валами, в яких прямокутні комірки розташовані у шаховому порядку, або зі зміщенням одного ряду комірок відносно іншого.

Правильне шахове розташування квадратних клейових зон (рис. 5, а) поділяє конструктивну поверхню приклеєної деталі обкладинки навпіл: 50 \% площі обкладинки з нанесеним клеєм, 50 \% - без клею. На рис. 5, б зображені квадратні клейові зони із суміщенням на розмір розтискування клею $\Delta(\mathrm{s}-\Delta)$.

Загальна площа клейової поверхні дорівнює:

$$
\begin{aligned}
& \mathrm{S}_{\text {кл(б) }}=\frac{\pi \mathrm{D}}{(\mathrm{t}+\Delta)+(\mathrm{s}-\Delta)} . \\
& \cdot \mathrm{v}(\mathrm{t}+\Delta) \cdot \mathrm{m}=\frac{\pi \mathrm{D}}{\mathrm{s}+\mathrm{s}-\Delta} . \\
& \cdot \mathrm{s} \cdot \mathrm{m}=\frac{\pi \mathrm{D}}{2 \mathrm{~s}-\Delta} \cdot \mathrm{s} \cdot \mathrm{m} .
\end{aligned}
$$

На рис. 5, в зображено квадратні клейові зони із суміщенням на розмір подвійного розтискування клею $2 \Delta(s-2 \Delta)$.

Загальна площа клейової поверхні дорівнює:

$$
\begin{aligned}
& \mathrm{S}_{\text {кл(в) }}=\frac{\pi \mathrm{D}}{(\mathrm{t}+\Delta)+(\mathrm{s}-2 \Delta)} . \\
& \cdot(\mathrm{t}+\Delta) \cdot \mathrm{m}=\frac{\pi \mathrm{D}}{\mathrm{s}+\mathrm{s}-2 \Delta} \cdot \mathrm{s} . \\
& \mathrm{m}=\frac{\pi \mathrm{D}}{2(\mathrm{~s}-\Delta)} \cdot \mathrm{s} \cdot \mathrm{m} .
\end{aligned}
$$

Для проведення експериментальних досліджень міцності обкладинок відібрані обкладинки, у яких розгортки для заготовки висічені із тонкого картону хромерзац товщиною 0,3 мм. Приклеювання клапанів півжорстких обкладинок до основної частини виконано після нанесення клею у способи перелічені в попередньому описі, що внесені до табл. 1.

Експериментальні дослідження виконувалися на розривній машині РМБ-30 з граничним навантаженням не менше $50 \mathrm{H}$ (5 кГс), ціною поділки шкали А не більше 0,02 кГс і вантажем, що створює зусилля на розрив біля 0,001 МПа (0,01 кГс/см²).

Для випробовування виділені фрагменти склеєних обкладинок, які являють собою смужки тонкого картону хром-ерзац, товщиною 0,3 мм, довжиною 100 мм і шириною 15 мм, склеєні у вищезазначені способи. 
Способи нанесення клею на конструктивні деталі

Таблиця 1 півжорстких обкладинок

\begin{tabular}{|c|c|l|c|}
\hline № & Кодування & \multicolumn{1}{|c|}{$\begin{array}{c}\text { Назва способу склеювання } \\
\text { експериментальних зразків }\end{array}$} & $\begin{array}{c}\text { Площа } \\
\text { ділянок без } \\
\text { клею, \% }\end{array}$ \\
\hline 1 & А & Суцільний & 0 \\
\hline 2 & Б & $\begin{array}{l}\text { Стрічковий з ділянками однакових розмірів, } \\
\text { розташованих у поздовжньому напрямку }\end{array}$ & 50 \\
\hline 3 & В & $\begin{array}{l}\text { Стрічковий з ділянками однакових розмірів, } \\
\text { розташованих у поперечному напрямку }\end{array}$ & 50 \\
\hline 4 & Г & $\begin{array}{l}\text { Шаховий, з однаковими розмірами квад- } \\
\text { ратних ділянок з клеєм і ділянок без клею }\end{array}$ & 50 \\
\hline 5 & Д & Шаховий зі зміщенням & 40 \\
\hline
\end{tabular}

Склеювання зразків здійснювались за допомогою сучасних палітурних клеїв: PLAKAL Batch 6602 (Німеччина), термоклей Tecnomelt 3660 (Німеччина), термоклей Swifttherm 8026 (Фінляндія), дисперсія полівініл-ацетатна ПВАД 51-П (Україна), дисперсія полівініл-ацетатна ПВАД ДФ-51/15В (Україна).

Результати проведених досліджень занесені до табл. 2.
На гістограмі, зображеній на рис. 6, відтворено порівняльні показники міцності склеєних, у способи вказані в табл. 1, фрагментів півжорстких обкладинок. Порівняння показників міцності відтворює не стільки відмінність способів склеювання розгорток півжорстких обкладинок, як залежність показників міцності від площі заповнення поверхонь склеювання та геометричної конфігурації нанесеного клею.

Рис. 6. Порівняльні показники міцності склеєних фрагментів півжорстких обкладинок 
Таблиця 2

Результати експериментальних досліджень склеєних фрагментів півжорстких обкладинок

\begin{tabular}{|c|c|c|c|c|c|c|c|c|c|}
\hline & \multirow{3}{*}{$\begin{array}{c}\text { Спосіб } \\
\text { склею- } \\
\text { вання } \\
\text { (коду- } \\
\text { вання із } \\
\text { табл. 1) }\end{array}$} & \multirow{3}{*}{ Назва клею } & \multicolumn{5}{|c|}{ Руйнівне зусилля } & \multirow{3}{*}{$\begin{array}{c}\text { Серед- } \\
\text { нє всіх } \\
\text { зраз- } \\
\text { ків, кГС }\end{array}$} & \multirow{3}{*}{$\begin{array}{l}\text { Міц- } \\
\text { ність під } \\
\text { нас роз- } \\
\text { тягу- } \\
\text { вання, } \\
\text { КГс/см }\end{array}$} \\
\hline $\begin{array}{l}\text { № } \\
\Pi / \Pi\end{array}$ & & & \multicolumn{5}{|c|}{ Номер зразків } & & \\
\hline & & & 1 & 2 & 3 & 4 & 5 & & \\
\hline \multirow{5}{*}{1} & (A) & $\begin{array}{c}\text { PLAKAL Batch } \\
6602\end{array}$ & 28,7 & 28,5 & 28,5 & 28,3 & 28,5 & 28,5 & 19,0 \\
\hline & - & $\begin{array}{c}\text { Термоклей } \\
\text { Tecnomelt } 3660\end{array}$ & 29,2 & 29,3 & 29,2 & 29,3 & 29,5 & 29,3 & 19,53 \\
\hline & $-"$ & $\begin{array}{c}\text { Термоклей } \\
\text { Smifttherm } 8028\end{array}$ & 29,1 & 29,2 & 29,6 & 28,8 & 28,8 & 29,1 & 19,4 \\
\hline & -" & ПВАД ДФ 51/15В & 30,5 & 30,5 & 30,5 & 30,6 & 30,4 & 30,2 & 20,13 \\
\hline & _"- & ПВАД 51-П & 30,0 & 30,2 & 30,0 & 30,4 & 30,4 & 30,2 & 20,13 \\
\hline \multirow{5}{*}{2} & (Б) & $\begin{array}{l}\text { PLAKAL Batch } \\
6602\end{array}$ & 17,9 & 17,8 & 17,9 & 17,7 & 17,9 & 17,84 & 11,89 \\
\hline & $-"$ & $\begin{array}{c}\text { Термоклей } \\
\text { Tecnomelt } 3660\end{array}$ & 19,2 & 19,4 & 19,3 & 19,2 & 19,0 & 19,22 & 12,81 \\
\hline & $-"-$ & $\begin{array}{c}\text { Термоклей } \\
\text { Smifttherm } 8028\end{array}$ & 19,0 & 19,2 & 19,2 & 19,0 & 19,1 & 20,1 & 13,40 \\
\hline & - & ПВАД ДФ 51/15В & 21,7 & 21,8 & 21,8 & 21,7 & 21,6 & 21,72 & 14,48 \\
\hline & _"- & ПВАД 51-П & 21,3 & 21,3 & 21,4 & 21,3 & 21,3 & 21,32 & 14,21 \\
\hline \multirow{5}{*}{3} & (B) & $\begin{array}{c}\text { PLAKAL Batch } \\
6602\end{array}$ & 16,9 & 17,0 & 16,9 & 17,1 & 17,2 & 17,02 & 11,34 \\
\hline & $-"-$ & $\begin{array}{c}\text { Термоклей } \\
\text { Tecnomelt } 3660\end{array}$ & 17,8 & 18,0 & 17,9 & 18,1 & 18,2 & 18,0 & 12,00 \\
\hline & $-"$ & $\begin{array}{c}\text { Термоклей } \\
\text { Smifttherm } 8028\end{array}$ & 17,7 & 17,7 & 17,8 & 17,8 & 17,9 & 17,78 & 11,85 \\
\hline & -"- & ПВАД ДФ 51/15В & 19,2 & 19,2 & 19,3 & 19,2 & 19,3 & 19,24 & 12,82 \\
\hline & _"- & ПВАД 51-П & 19,0 & 18,9 & 18,9 & 18,8 & 19,0 & 18,92 & 12,61 \\
\hline \multirow{5}{*}{4} & (Г) & $\begin{array}{c}\text { PLAKAL Batch } \\
6602\end{array}$ & 18,9 & 18,8 & 18,9 & 18,7 & 18,8 & 18,82 & 12,54 \\
\hline & $-"$ & $\begin{array}{c}\text { Термоклей } \\
\text { Tecnomelt } 3660\end{array}$ & 19,8 & 19,8 & 19,9 & 19,9 & 19,9 & 19,84 & 13,22 \\
\hline & $-"-$ & $\begin{array}{c}\text { Термоклей } \\
\text { Smifttherm } 8028\end{array}$ & 19,6 & 19,6 & 19,7 & 19,8 & 19,7 & 19,68 & 13,12 \\
\hline & -”- & ПВАД ДФ 51/15В & 22,7 & 22,6 & 22,7 & 22,8 & 22,6 & 22,68 & 15,12 \\
\hline & _"- & ПВАД 51-П & 23,0 & 23,1 & 23,2 & 23,0 & 23,3 & 23,12 & 15,41 \\
\hline
\end{tabular}


Закінчення табл. 2

\begin{tabular}{|c|c|c|c|c|c|c|c|c|c|}
\hline \multirow{3}{*}{$\begin{array}{l}\text { № } \\
\text { п/ }\end{array}$} & \multirow{3}{*}{$\begin{array}{c}\text { Спосіб } \\
\text { склею- } \\
\text { вання } \\
\text { (коду- } \\
\text { вання із } \\
\text { табл. 1) }\end{array}$} & \multirow{3}{*}{ Назва клею } & \multicolumn{5}{|c|}{ Руйнівне зусилля } & \multirow{3}{*}{$\begin{array}{c}\text { Серед- } \\
\text { нє всіх } \\
\text { зраз- } \\
\text { ків, кГс }\end{array}$} & \multirow{3}{*}{$\begin{array}{c}\text { Міц- } \\
\text { ність під } \\
\text { час роз- } \\
\text { тягу- } \\
\text { вання, } \\
\text { кГс/см }\end{array}$} \\
\hline & & & \multicolumn{5}{|c|}{ Номер зразків } & & \\
\hline & & & 1 & 2 & 3 & 4 & 5 & & \\
\hline \multirow{5}{*}{5} & (Д) & $\begin{array}{l}\text { PLAKAL Batch } \\
6602\end{array}$ & 26,7 & 26,5 & 26,5 & 26,3 & 26,5 & 26,5 & 17,66 \\
\hline & $-"$ & $\begin{array}{c}\text { Термоклей } \\
\text { Tecnomelt } 3660\end{array}$ & 27,2 & 27,3 & 27,2 & 27,3 & 27,5 & 27,3 & 18,2 \\
\hline & - & $\begin{array}{c}\text { Термоклей } \\
\text { Smifttherm } 8028\end{array}$ & 27,1 & 27,2 & 27,6 & 26,8 & 26,8 & 27,1 & 18,06 \\
\hline & -"- & ПВАД ДФ 51/15В & 28,5 & 28,5 & 28,5 & 28,6 & 28,4 & 28,5 & 19,0 \\
\hline & _"- & ПВАД 51-П & 28,0 & 28,2 & 28,0 & 28,4 & 28,4 & 28,2 & 18,8 \\
\hline
\end{tabular}

Експериментальні дослідження показали незмінність структури склеєних півжорстких обкладинок, незважаючи на спосіб склеювання, після їх приклеювання до форзаців книжкових блоків, і відсутність зовнішніх дефектів у вигляді пухирів різних розмірів або розшарувань самої обкладинки.

Отже, застосовуючи різні способи склеювання конструктивних деталей півжорстких обкладинок, необхідно у кожному технологічному випадку визначати площу заклеювання, відповідні витрати клею для кожного способу і отриману, в результаті склеювання, міцність обкладинок, яка відповідає їх експлуатаційній стійкості.

Порівняно з суцільним заклеюванням (кодування А в табл. 1) конструктивних поверхонь півжорстких обкладинок, зменшення показників міцності, відповідно способу нанесення клею складає: Б - 13,9 \%; В - 15,7 \%; Г 13,06 \%; Д - 10,6 \%.
Найбільш сприятливим для застосування виявився спосіб коміркового шахового нанесення палітурного клею із частковим осьовим зміщенням клейових клітинок. При 40 \% економії клею міцність склеєної півжорсткої обкладинки зменшується лише на 10,6 \% порівняно із суцільноклеєною.

\section{Висновки}

Дослідження можливостей мінімізації кількісного застосування клейових полімерних композицій, при виготовленні півжорстких книжково-журнальних обкладинок, за рахунок дискретного нанесення клею суцільним стрічковим методом із повздовжнім або поперечним напрямком, а також комірковим шаховим методом, виявили непропорційні відмінності у міцності утворених обкладинок і геометричною площиною заповнюваності клеєм.

Порівняння показників міцності склеєних фрагментів півжорстких обкладинок, отриманиху результаті досліджень, відтворюють 
відмінності способів склеювання розгорток півжорстких обкладинок, а також залежності показників міцності від площі заповнення поверхонь склеювання і конфігурації нанесеного клею.

При проведені експериментальних досліджень виявлено, що неоднорідність склеєної просторової конструкції півжорстких обкладинок, утворена дискретним склеюванням, не вплинула на появу зовнішніх дефектів у вигляді пухирів різних розмірів або розшарувань самої обкладинки.

У технологічних розрахунках для визначення площі клею, що наноситься стрічковим або комірковим клейовим валом на обкладинку, з параметрами формату видання, мають застосовуються коефіцієнти переходу, які враховують розміри клейового валу виробничого механізму нанесення клею, а також враховують довжину і ширину клейової ділянки обкладинки.

Отримані результати досліджень дискретних способів склеювання конструктивних деталей розгорток півжорстких книжковожурнальних обкладинок, висічених із одного щільного палітурного матеріалу, створюють додаткові можливості в плануванні економного використання витратних матеріалів, при виготовленні склеєних обкладинок, виходячи із умов забезпечення їх експлуатаційної стійкості.

\section{Список використаної літератури}

1. Палюх О. О. Експериментальне визначення міцності склеєних зразків паперу і картону для виготовлення книжково-журнальних обкладинок і палітурок різних конструкцій / О. О. Палюх // Технологія і техніка друкарства. 2017. № 4(58). C. 11-24. DOI: https://doi.org/10.20535/2077-7264.4(58). 2017.132540.

2. А. Рудавская. Технология склеивания / А. Рудавская // Обработка поверхности в технологии склеивания. 2019. С. 7-46. https://doi.org/10.1016/ b978-0-12-817010-6.00002-3.

3. Джон Эндрюс Арнетт. Bibliopegia или Искусство переплетного дела во всех его ветвях. 2019. https://doi.org/10.4324/9780429030420-1.

4. Suzanne Wilson-Higgins. Trends in book manufacturing on-demand. The Impact of Print-On-Demand on Academic Books. 2018. pp. 119-132.

5. Liebau D. Industrielle Buhbinderei / D. Liebau, I. Heinze. Itzehoe, 2007.

6. Палюх О. О. Дослідження конструктивних відмінностей окремих видів півжорстких обкладинок / О.О.Палюх // Технологія і техніка друкарства. 2018. № 4(62). C. 48-59. DOI: https://doi.org/10.20535/2077-7264.4(62).2018.145370.

7. Гавенко С. Ф. Кінетика пошкодження і руйнування клейових з'єднань при експлуатації / С. Ф. Гавенко // Поліграф. і вид. справа. 2012. № 3. С. 91-96.

8. Petriaszwili G. Wpływ parametrów obróbki grzbietów wkładów na jakość łączenia klejowego / G. Petriaszwili, R. Merwiński, J. Gaweł // Światdruku. 2003. № 11. pp. 21-23.

9. Jędrasik K. Digital workflow w introligatorni / K. Jędrasik, G. Petriaszwili, J. Chwedczyn // Poligrafika. 2006. № 9. pp. 48-50.

10. Petriaszwili G. Analysis of a Model of the Adhesive Layer between Two Sheets of Paper / G. Petriaszwili, J. Pyrjev // Journal of Vibroengineering, September 2008. V. 10. pp. 282-284. 
11. Воробьев Д. В. Технология послепечатных процессов. М.: МГУП. 2007. 393 c.

12. Malkolm G. Keif. Designer's postpress companion. National Association for Printing Leadership. Paramus, New Jersey. 2005. 276 p.

13. Clark T. Bookbinding with adhesives. England: cGRAW-HILL Book Company Europe. 2007. p. 53.

14. Jerman P. Reflections on Book Structure-Part 3-Spine Control, [online]: http://temperproductions.com/Bookbinding\%20Howto/Reflections/Reflection s\%203\%20\%20Spine\%20. Control. pdf (21.3.2015).

15. Kipphan $\mathrm{H}$. Handbook of print media: Technologies and production methods. Springer. 2001. p. 837.

\section{References}

1. Paliukh, O. O. (2017). Eksperymentalne vyznachennia mitsnosti skleienykh zrazkiv paperu i kartonu dlia vyhotovlennia knyzhkovo-zhurnalnykh obkladynok i paliturok riznykh konstruktsii. Journal of Tekhnolohiia i tekhnika drukarstva, 4(58), 11-24. DOI: https://doi.org/10.20535/2077-7264.4(58). 2017.132540 [in Ukrainian].

2. Rudavskaya, A. (2019). Tekhnologiya skleivaniya. Journal of Obrabotka poverkhnosti v tekhnologii skleivaniya, 7-46. https://doi.org/10.1016/b978-012-817010-6.00002-3 [in Russian].

3. Arnett, Dzhon Endryus. (2019). Bibliopegia ili Iskusstvo perepletnogo dela vo vsekh ego vetvyakh. https://doi.org/10.4324/9780429030420-1 [in Russian].

4. Wilson-Higgins, Suzanne. (2018). Trends in book manufacturing on-demand. The Impact of Print-On-Demand on Academic Books, 119-132 [in English].

5. Liebau, D. \& Heinze, I. (2007). Industrielle Buhbinderei. Itzehoe [in German].

6. Paliukh, O. O. (2018). Doslidzhennia konstruktyvnykh vidminnostei okremykh vydiv pivzhorstkykh obkladynok. Journal of Tekhnolohiia i tekhnika drukarstva, 4(62), 48-59. DOI: https://doi.org/10.20535/2077-7264.4(62).2018. 145370 [in Ukrainian].

7. Havenko, S. F. (2012). Kinetyka poshkodzhennia i ruinuvannia kleiovykh z'iednan pry ekspluatatsii. Journal of Polihraf. i vyd. sprava, 3, 91-96 [in Ukrainian].

8. Petriaszwili, G. \& Merwiński, R. \& Gaweł, J. (2003). Wpływ parametrów obróbki grzbietów wkładów na jakość łączenia klejowego. Journal of Światdruku, 11, 21-23 [in Polish].

9. Jędrasik, K. \& Petriaszwili, G. \& Chwedczyn, J. (2006). Digital workflow w introligatorni. Journal of Poligrafika, 9, 48-50 [in Polish].

10. Petriaszwili, G. \& Pyrjev, J. (2008). Analysis of a Model of the Adhesive Layer between Two Sheets of Paper. Journal of Vibroengineering, V. 10, 282-284 [in English].

11. Vorob'ev, D. V. (2007). Tekhnologiya poslepechatnykh protsessov. Moscow: MGUP, 393 p. [in Russian].

12. Malkolm, G. Keif. (2005). Designer's postpress companion. National Association for Printing Leadership. Paramus, New Jersey, 276 p. [in English].

13. Clark, T. (2007). Bookbinding with adhesives. England: cGRAW-HILL Book Company Europe, p. 53 [in English].

14. Jerman, P. Reflections on Book Structure-Part 3-Spine Control. Retrieved from http://temperproductions.com/Bookbinding\%20Howto/ Reflections/Reflections\%203\%20\%20Spine\%20 [in English].

15. Kipphan, H. (2001). Handbook of print media: Technologies and production methods. Springer, p. 837 [in English]. 


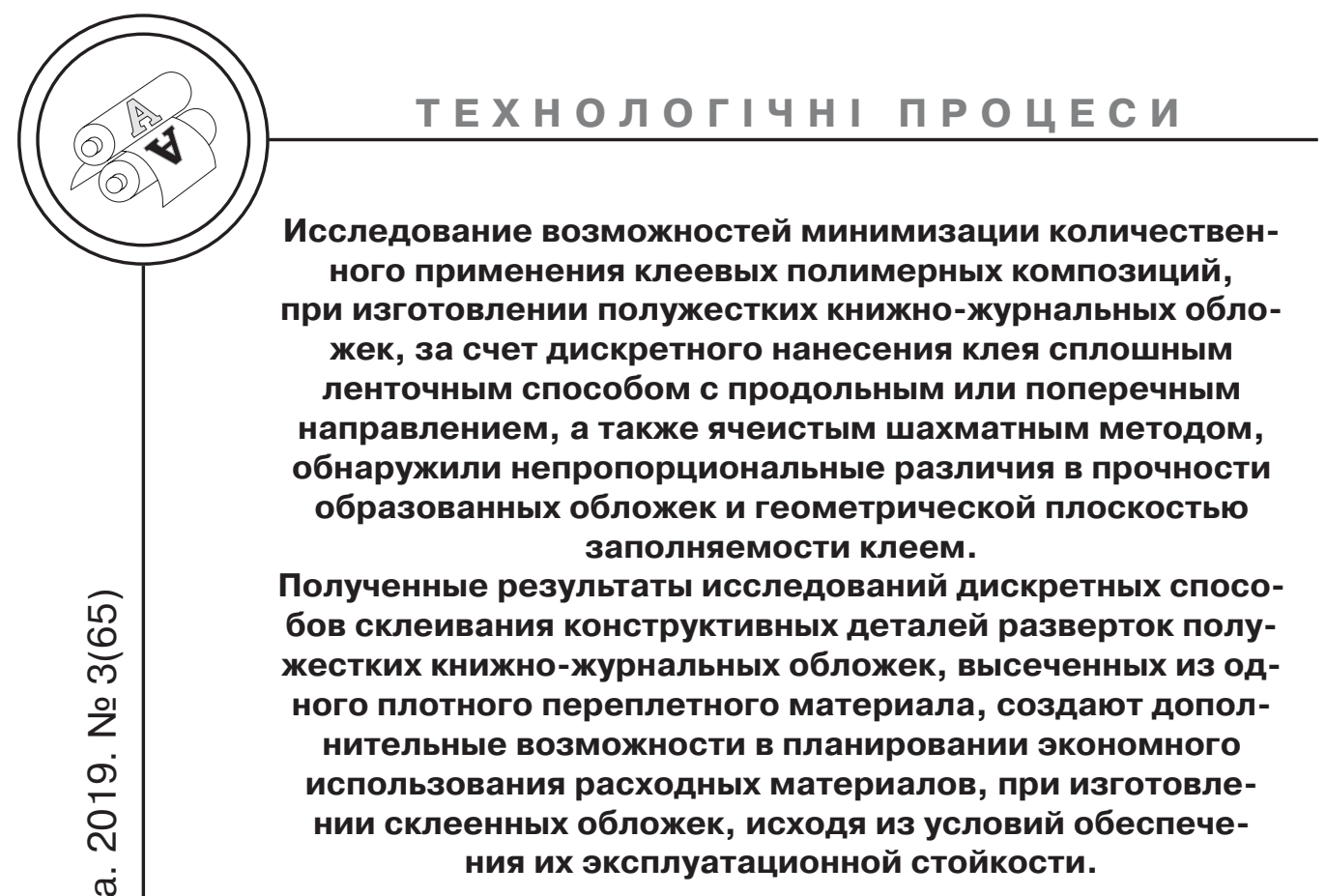

Ключевые слова: полужесткая обложка; развертка обложки; ленточное нанесение клея; ячеистое нанесение клея; дискретное склеивание.

Investigation of the possibilities of minimizing the quantitative application of adhesive polymer compositions, in the manufacture of semi-rigid book-magazine covers, due to the discrete application of adhesive by continuous tape method with a longitudinal or transverse direction, as well as cellular checkered method.

The obtained results of studies of discrete methods of gluing structural details of the semi-rigid book-magazine covers, cut from one dense binding material, create additional opportunities in planning the economical use of consumables, in the manufacture of glued covers, based on the conditions of their maintenance.

Keywords: semi-rigid cover; cover outline; tape adhesive application; cell adhesive application; discrete bonding. 